\title{
The Teacher and Teaching Polish as a Second Language in the Contemporary Educational Reality
}

KEYWORDS

Polish as a second language, students with migration backgrounds, acculturation of the foreigners, Polish glottodidactics

\begin{abstract}
An increasing number of immigrants arrive in our country, not all of whom treat Poland only as a transit stop on their way to wealthier countries of the Western Europe. What this means for the Polish society, with its cultural and linguistic homogeneity, is a direct confrontation with cultural and religious otherness, represented by the settling newcomers. Unfortunately, the educational establishments are not sufficiently prepared to take in new students with migration backgrounds. The entire situation also poses an enormous challenge for polonistic glottodidactics, actively present in the process of acculturation of the foreigners. The undertaken actions are primarily focused on organising and conducting classes in Polish as a second language. An important element to ensure the proper execution of the discussed process is the education of teachers, the presentation of which is a principal goal of this text.
\end{abstract}

\section{Introduction. Social context}

According to statistics, Poland remains a country of emigration and not immigration. The increasingly pressing issues of refugee influx, chiefly from war-torn areas of Asia and Africa have been hardly present in the public debate in Poland. The politicians would rather use the foreigners as a fear factor to pursue their own goals, rather than engage in Europe-wide support actions for refugees. The unfavourable political climate, however, was not enough to interrupt the long-term grassroots educational initiatives, undertaken within the Polish education system and aimed at cultural and linguistic acculturation of the students with migration backgrounds. The stable economic growth and changing international image of the Polish state have translated into an increased interest in settling in Poland. An increasing number of immigrants arrive in our country, not all of whom treat Poland 
only as a transit stop on their way to wealthier countries of the Western Europe. The economic depression in most parts of Europe serves as additional encouragement to settle in Poland. What this means for the Polish society, with its cultural and linguistic homogeneity, is a direct confrontation with cultural and religious otherness, represented by the settling newcomers. The result is a major challenge for the Polish education system. Unfortunately, the educational establishments are not sufficiently prepared to take in new students with migration backgrounds. The entire situation also poses an enormous challenge for polonistic glottodidactics, as an active factor in the process of acculturation of the foreigners. The undertaken actions are primarily focused on organising and conducting classes in Polish as a second language.

\section{Polish as a second language vs. Polish as a foreign language. Terminology solutions}

The term Polish as a Second Language remains far from being widespread, even among the polonistic glottodidactic staff. On the contrary a term such as Polish as a Foreign Language would still surface not only in the general academic nomenclature but also to denote glottodidactic tasks addressed to students with migration backgrounds. The first definition of the field of research into didactics of Polish as a second language, based on well-established didactic systems of the particular languages-as-second in other countries of Europe, has been suggested in a study by Władysław T. Miodunka (2010). It is his conviction that the term Teaching Polish as a Second Language should be used [...] with regards to teaching the Polish language in the area of Poland to children of immigrants and political refugees, as well as children belonging to ethnic minorities, wherein the language of everyday communication is different (Miodunka 2010: p.233). The definition proposed by the above-mentioned scholar includes the suggestions towards the description of the discipline at hand, coined by the French researchers Jean-Pierre Cuq and Isabelle Gruca, as well as the English-speaking David Crystal, Keith Johnson and Helen Johnson ${ }^{1}$. This definition, as proposed by the Cracovian scholar, should well be implemented into the current systemic solutions in Poland. The worthwhile distribution of detailed areas of didactic activity follows in Table 1.

\footnotetext{
${ }^{1}$ Cf. Cuq, J.-P., Gruca, I., Cours de didactique du français langue étrangère et seconde, Paris 2005; Crystal D., The Cambridge Encyclopedia of Language, Cambridge 1989; Johnson K., Johnson H. (Ed.), Encyclopedic Dictionary of Applied Linguistics, Malden 1999.
} 
Table 1. Polish as a second language vs. Polish as a foreign language within the Polish glottodidactic space (author's work)

\begin{tabular}{|c|c|c|}
\hline & $\begin{array}{l}\text { Public schooling (children and } \\
\text { adolescents) }\end{array}$ & Adult education \\
\hline $\begin{array}{l}\text { Polish } \\
\text { as a foreign } \\
\text { language (PFL) }\end{array}$ & $\begin{array}{l}\text { - Teachers in Polish schooling abroad or in } \\
\text { foreign schooling with Polish as a foreign } \\
\text { language; } \\
\text { - All stages of education, including the } \\
\text { initial schooling period and bilingual } \\
\text { teaching; } \\
\text { - International school exchange } \\
\text { programmes (Polish teachers in partner } \\
\text { schools abroad and students from abroad } \\
\text { in Polish schools). }\end{array}$ & $\begin{array}{l}\text { - Lecturers in universities abroad; } \\
\text { - Lecturers in local universities, adult } \\
\text { education and development facilities, } \\
\text { language schools as well as language } \\
\text { courses within commercial enterprises. }\end{array}$ \\
\hline $\begin{array}{l}\text { Polish as } \\
\text { a second } \\
\text { language (P2L) }\end{array}$ & $\begin{array}{l}\text { - Teachers to students with migration } \\
\text { backgrounds (including children returning } \\
\text { to Poland after a time abroad), as public } \\
\text { schooling staff; } \\
\text { - Polish as second language courses in } \\
\text { kindergartens; } \\
\text { - Wide support to children with migration } \\
\text { backgrounds outside the education } \\
\text { facilities. }\end{array}$ & $\begin{array}{l}\text { - Polish language lectors for people with } \\
\text { migration backgrounds, as employed in } \\
\text { adult education and training facilities, } \\
\text { language schools, as well as providing } \\
\text { language courses for commercial } \\
\text { enterprises }\end{array}$ \\
\hline
\end{tabular}

A precise definition of the didactic fields of Polish as a second or foreign language is a matter of key importance to all specialised staff, employed in teaching foreigners. This is due to the inherent discrepancies in didactic goals and conducting classes in diverse educational contexts. In the case of teaching Polish as a second language, the students are usually individuals with migration backgrounds. Polish as a foreign language on the other hand, is mostly learnt by foreigners abroad and individuals without the intention of a prolonged stay in Poland. Within the former field the crucial component of any educational process is comprised of activities aimed at acculturation, conducted parallel to the development of active communication competences. The latter though, is dominated by developing practical communication skills, with intercultural competences as a side topic only. What this results in, is a radical inversion of the didactic priorities. Having taken the above into account, it does seem peculiar that the term Polish as a Foreign Language is so much abused in the polonistic glottodidactic communities, also with regards to working with immigrant students. The same is true for the nomenclature in official legislative documentation and the names of academic glottodidactic specialisations. The term Polish as a Second Language is mostly familiar to a close group of specialists, affiliated with the Jagiellonian University or the University of Łódź. It is also immediately visible in the differentiation of teaching content in post-graduate 
studies offered by the two universities, where the two fields of polonistic glottodidactics are clearly separated. It would be advisable that this example is widely followed, since the chaotic terminology at hand seems to pose a threat from a yet another perspective. It is a hindrance to the education authorities fully appreciating the necessity to create legislative grounds for the new, emergent type of teacher. A specialisation which has yet to be included into the Regulated Occupations listing. Not to mention the fact, that neither does the above include the teachers of Polish as a foreign language, even though it is an occupation formally performed in Poland since 1931. Should we add to the above the consideration that the new syllabus for elementary schooling takes precisely no account of the presence of students with migration backgrounds in Polish schools, then a distressing conclusion becomes self-evident; that the Polish education system assumes apriori the realisation of classes of Polish as second language (invariably termed as foreign in all official contexts) in a manner which is both pre-planned from the legislative point of view and properly documented by adequate directives, even though the staff to actually fulfil these tasks is technically non-existent. The staff which none the less is being educated, with growing popularity, as can be concluded from the ever-greater number of candidates. The above conundrum might be the reason why these specialised staff, competing for employment in their field, are often at a disadvantage compared to other teachers, predominantly traditional polonists. This is due to the fact that the existence of the latter is widely acknowledged among the headmasters and headmistresses, even though a traditional polonist is hardly equipped to perform glottodidactic tasks. To this day the specialised staff to teach Polish as a second language (or even as a foreign language) formally don't exist.

\section{The first initiatives to educate teachers of Polish as a second language.}

The key factor to ensure the professional performance of any tasks with regards to teaching Polish as a second language in an average Polish school is the education and development of specialised staff, which should be prepared to conduct cultural and language education of students with migration backgrounds. The recent years have seen the first initiatives being undertaken to forward this goal. To name but a few, educational content relevant to teaching Polish as a second language has been included in curricula for the respective specialisations at The Centre for Polish Language and Culture in the World of the Jagiellonian University, the Polish Philology at the University of Łódź and Polish Philology at the Pedagogi- 
cal University of Kraków. Consequently, the official names of the specialisations have been amended to Teaching Polish as a Foreign or Second Language ${ }^{2}$. A new glottodidactic specialisation has also been launched at The Institute of Applied Polish Studies of the Warsaw University within the undergraduate full-time programme, to educate teachers of Polish language to teach students with migration backgrounds in primary and middle schools. This Warsaw University also offers post-graduate studies for teachers based in Warsaw, working with immigrant children and adolescents. Their description of the specialisations, however, does not use the term Teaching Polish as a Second Language. The curriculum itself also bears much resemblance to the education of teachers of Polish as a foreign language, and not as second, lacking practically any components which would prepare the teachers to perform didactic acculturation tasks.

\section{Paradigms and pedeutological models vs. the education of teachers of Polish as a second language}

The first detailed pedeutological research within the developing field of Polish glottodidactics has only been undertaken as late as during the 1980s. It was then that the scientific background for the education of foreign language teachers started to be formulated. The academic pedeutology, having emerged within the field of the developing pedagogy, has come an arduous way to its deserved position within the interests of Polish neophilologists, for whom any pursuits in the glottodidactics have long been tantamount to dedicating themselves to scientific research of a lower rank and esteem. Teaching the prospective foreign language education staff, even though it should be the main goal of the pre-service education for all neophilology students, has also long been relegated to what could be described as a scientific periphery. In addition to the above, the Polish neophilologist circles of the 1980s assumed their pedeutological solutions under a major influence of the dominant political doctrine, which dictated the final shape of any type of academic programme in the philology studies. Strong emphasis was consequently placed on the inclusion of Russian, English, German and Romance studies, from where the future teaching staff would be recruited. There have been, although scattered, attempts to introduce to the academic debate a selection of notions inclusive of

\footnotetext{
2 The profile name change was concurrent with supplementing the curriculum with content relevant to a future role of the teacher of Polish as a second language in public schooling in Poland. The newly initiated classes include e.g. in Kraków: Teaching Polish as a Second Language and Introduction to Intercultural Glottopedagogy
} 
the solutions borrowed from the West, as well as the results of the local, if scarce, glottolinguistic research in pedeutology. These could be found i.a. in the 1988 conference proceedings edited by Franciszek Grucza, and titled The Issues of Foreign Language Teacher Education (Problemy kształcenia nauczycieli języków obcych) as an aftermath of a pedeutological conference organised by the Institute of Applied Linguistics in Warsaw.

Pedeutology was hardly a topic though, in the field of academic research and critical thinking undertaken by the scholars in teaching Polish to foreigners. At the beginning of 1980s the "Polonicum" association in Warsaw has nevertheless acquired the state consent to launch the first Post-Graduate Studies in Teaching Polish as a Foreign Language. Even though it was in major improvement, the design concept behind the scheduled classes only mirrored the dominant notion in polonistic glottodidactics at the time, which was the rational empiricism in its methodological aspect. The prospective specialists were taught by active practitioners and the novice adepts of the recently developed polonistic glottodidactics. The appalling lack of specialised glottodidactic teaching personnel was clearly visible in the curriculum. Dominated by classes in linguistics, Polish literature and culture studies, it never provided the much-needed space for academic background research to account for the specificity of the glottodidactic process. The actual methodology was taught on the basis of the personal experience of the teaching staff. The rationale behind which was that the more experienced a lecturer was in teaching a language, the more valuable their methodological input would be. Simultaneously another Polish facility opted to begin organising the first, irregular formulae of educational potential for language teachers. This was the Institute of Polish Diaspora at the Jagiellonian University, and precisely its Department of Applied Linguistics for Teaching Polish as a Foreign Language (the predecessor of the unique Faculty of Polish as a Foreign Language, est. 2005), at that time under the supervision of Władysław Miodunka. At the beginning of 1980s regular courses and trainings were launched in polonistic glottodidactics for aspiring lecturers, alongside the development classes for active teachers of Polish to foreigners. The education profile had been conceived along the lines of the concurrent individual research projects by the members of the Department's academic staff. Consequently, a much-needed scientific approach could be provided, although in the beginnings it only resulted in running short-term courses in pedeutology.

The early 1990s though, saw a growing demand for teachers of foreign languages and the following need to establish a new system to educate the necessary personnel. Owing to this new impulse pedeutology has become more frequent 
a topic in academic discourse and research among the neophilological glottodidactics scholars. In order to formulate new concepts for the education of foreign language teachers, research has been undertaken with the greatest emphasis on the key functions of foreign language teachers and the main tasks they need to accomplish in their day to day work. The glottodidactic knowledge among neophilologists has also come under closer scrutiny and other intersectional competences and skills emerged alongside as advisable. Attempts were made to establish a theoretical reference image of a model foreign language teacher.

A certain list of skills has been published in Teaching a Foreign Language. From Practice to Practice (Nauka języków obcych. Od praktyki do praktyki. ) in 2001 by Waldemar Pfeiffer, affiliated with the Institute of Applied Linguistics in Poznań. Therein were given the ten key functions of foreign language teacher, including tasks of organisation, education, design, activisation, individualisation, motivation, leadership, supervision, tutelage and interpretation of culture. (Pfeiffer 2001: p.122). Pfeiffer's list does take into account the real expectations, drawn from the current state of research in glottodidactics, and in particular its dominant assumptions of communication-focused teaching aimed at undertaking language activities, and as such can well serve as background for establishing the basic areas of competence, which would be expected from contemporary pedagogues. Five such areas have been mentioned by Pfeiffer; language fluency, methodology, social and cultural knowledge, pedagogical and media skills. Each of them has been attributed a detailed range of activities in everyday teaching practice.

On the other hand, Hanna Komorowska, an associate of the English Philology Institute in Warsaw, in her Methodology in Teaching a Foreign Language (Metodyka nauczania języków obcych), published in 2002, indicated four key skills of a contemporary foreign language pedagogue in the relevant section of her work. These were: interactive, pedagogical, linguistic and didactic skills. In a manner similar to Pfeiffer, Komorowska also followed to provide a detailed description of the particular skill ranges. The interactive skill should be understood as the ability to provide an unambiguous set of rules of conduct to be adhered to during classes. Pedagogical skill should be sufficient to allow proper organisation of classes, where the students' autonomy and self-confidence is encouraged. Linguistic skill equals deepened understanding of the language and the corresponding culture, while the didactic skill is comprised of the practical competence to teach.

The above-mentioned attributes of a model teacher have since been regarded as certain guidelines for the undergoing process of educating the prospective teachers. The theoretical background, which came to define the teacher occupational functions and imply specific skill ranges and areas of competence, has been 
widely referred to in the relevant literature as the "premises for the academic education of teachers".

Neither the work by Pfeiffer nor the one by Komorowska could be fully described as substantial pedeutological models, even though their research and considerations did seem to ordinate the process of educating the foreign language teachers to some extent. A process which in the early 1990s has also become the cardinal goal pursued by the Teacher Colleges for Foreign Languages, scattered across the country. These establishments were meant to educate a new generation of glottodidactic personnel over three-year learning cycles in teaching English, German and French (later followed by Spanish, Italian and Russian). It should be noted however, that the Colleges have mostly ceased to exist in 2015. At present only two of such facilities remain, within the structures of the Warsaw University (for English, German and French) and the Silesian University of Technology in Gliwice (for English, German, French, Spanish and Italian).

The first proposal of a scientifically-backed pedeutological model can be found in a monograph published in 2004 by Elżbieta Zawadzka, a germanist affiliated with the Warsaw University, under the title Teachers of Foreign Languages in the Age of Transformation (Nauczyciele języków obcych $w$ dobie przemian). One should not hesitate to regard this work as a milestone, marking a further step in the development of glottodidactic thinking, as it attempts both to establish the first scientific models for teacher education and to research into the particular structural pieces of the said models. The author has also devoted a part of her work to elaborate on the development process in pedeutology over the previous decades, and to display the theoretical concepts and teacher education models established in the field of pedagogical pedeutology, also translating them into the terms of glottodidactic reality. Among the possible orientations in teacher education, as shown by Zawadzka, two are worth particular notice; a proposition by Henryk Mizerek (1999) and another by Henryka Kwiatkowska (1988). The former is centred on the four discourses concerning behaviourism, humanities, apprenticeship and reflection (Mizerek 1999) while the latter focuses on a triplet of theoretical models: the technological, the functional and the humanistic (Kwiatkowska 1988). It should be noted that the technological model in Kwiatkowska's work is a counterpart of the behavioural and apprenticeship discourses suggested by Mizerek. His notions of behaviourism and humanities on the other hand are contained in the humanistic model proposed by Kwiatkowska. This exact model had been referred to as academic background by H. Kwiatkowska and A. Kotusiewicz, who co-operated to create a modular concept for teachers' education, and single out a series of roughly self-contained learning units, corresponding to the occupational functions of the future teachers. 
Furthermore, Zawadzka has elaborated on this proposal and sketched the outlines of the first Polish model for foreign language teacher education, inclusive of the six key occupational functions: the expert - the tutor - the cultural middleperson - the organiser, moderator and advisor - the evaluator and innovator - the researcher and reflective practitioner. On the other hand, the humanistic model for teacher education in Zawadzka's considerations serves as a certain prototype for the methods to be adhered to during the live education process itself. What could be indicated as lacking in Zawadzka's work is the fact that she took no account of the two pedeutological paradigms, which had been widely discussed in European pedeutology of the time: the Paradigms of Constructivism and of Emancipation. The former had already infiltrated into glottodidactics, a discipline where the elements of constructivist problem-solving were being drawn upon ever more frequently. Elżbieta Zawadzka herself does find applications for many of the said elements. However, she regards them exclusively as attributes of the aforementioned humanistic model, and puts them to use with great consequence, to elaborate on the proposal by Kwiatkowska and Kotusiewicz, accepted as a prototype.

Zawadzka's set of teacher occupational functions has been developed beyond the author's scope by further research and analysis, which have found their way into more recent publications in Poland. To quote but an example, the function of cultural middleperson has become the main focus for i.a. Lucyna Aleksandrowicz-Pędich. Her paper Interculturalism within Foreign Language Classes (Międzykulturowość na lekcjach języków obcych), published in 2005, is a summary of the author's own research into the occurrences of culture-centred spotlights during foreign language classes. The results are a clear indicator that the current teacher education system is appallingly inefficient in developing the intercultural competences among the philology students, including those in the didactic specialisations. An integral, fundamental part of the pedeutological model by Elżbieta Zawadzka is thus lacking.

Another publication by Elżbieta Zawadzka-Bartnik was dedicated to the teacher functions as expert and tutor, titled A Foreign Language Teacher and Their Students with Disabilities (with Disorders and Dysfunctions) (Nauczyciel języków obcych i jego niepełnosprawni uczniowie (z zaburzeniami i dysfunkcjami) ), and printed in 2010. This work stands as the first paper in the field of Polish glottodidactics to address the challenges of teaching foreign languages in integration classes. Emphasis was placed on theoretical considerations to assess disabilities as an educational challenge as well as the very idea of integration schooling and the way it was being conducted in Poland. The local foreign language teacher education 
system is also discussed, as insufficient to prepare the didactic personnel to work with and support students with non-normative education needs.

The majority of scholars pursuing the topic of the teacher as researcher and innovator tends to propose the implementation of the humanistic pedeutological model, as well as, with increasing popularity, the Emancipation Paradigm into the Polish foreign language teacher education. The frequent working assumption is, that such an approach should encourage and reinforce the teachers' autonomy, which should in turn result in the growing level of autonomy among the students. Another group of researchers, however, tends to question the relevance of the above orientations to the Polish environment, predominantly claiming that the local reality of language education (both in the schools and universities) is far from the readiness to implement innovation. Such is the opinion of i.a. Weronika Wilczyńska, author of the article Foreign Language Teacher as Researcher (Nauczyciel języka obcego jako badacz), published in the aforementioned bundle Foreign Language Teacher - Today and Tomorrow (Nauczyciel języków obcych dziś i jutro) in 2009. Therein she elaborated as follows:

The occupational culture of our teachers, [...] seems to be centred on the criteria of efficiency and a "phenomenological" experience of didactics. Systematic reflection, let alone research into their own didactic practice would require a significant restructuring of the dominant mentality. First and foremost, the very foundation of our didactic activities would need to be amended, to conform [...] to the everyday practice [...] of research and critical awareness (Wilczyńska 2009: pp. 496-497).

In spite of the above, Wilczyńska does elsewhere advocate for a broader implementation of reflective approach into the occupational practice of teachers in Poland. The chance to actually fulfil such a goal seems to reside in furthering the notion to bring the education process of the prospective foreign language teachers yet closer to the academic dimension. According to Wilczyńska what is necessary, are lectures in communication skills and language activisation, and, equally important, courses in research training, to shed light on the design and application of research tools and definition of research queries. Students should also be familiarised with the specific features of academic discourse (ibid.: p.504).

The above-mentioned process of creating education opportunities for Polish teachers to facilitate working with foreigners, despite its growing rate after the accession of Poland to the EU (and the fact that it is currently active in 13 facilities) has yet to significantly influence the interest in pedeutological research in polonistic circles. New methodological publications have appeared, many of them meeting the requirements of an academic handbook, such as the Cracovian series Methodology of teaching Polish as a Foreign Language (Metodyka nauczania jezzy- 
ka polskiego jako obcego) and the Library of LingVaria. Glottodidactics (Biblioteka LingVariów. Glottodydaktyka) as well as the Silesian series Art or (and) Craft (Sztu$k a, c z y$ (i) rzemiosło). All of them addressed didactic and methodological issues of crucial importance to any potential teacher. What is still lacking though, are scientific publications in pedeutology, such as the ones already in circulation elsewhere in Europe, to discuss the occupational identities of teachers, their well-being as well as the core ideas of their education and further development. No systemic nor individual empirical research has been conducted in this field either. Scattered pedeutological publications did emerge. However, as opposed to the neophilological approach, they remained deeply embedded in the ideas of rational empiricism. Their authors would only proceed as far as sharing their own experiences of educating the future Polish teachers. As odd as this might seem, such a situation bore close resemblance to what was true at the very beginnings of the development of Polish glottodidactics in the 1970s and 80s.

This continued until as recently as 2013 , when the first pedeutological monograph to take teaching Polish both as foreign and second language into account was published. It was written by the undersigned and titled The Educational Models for Foreign Language Teachers in Poland and Germany. Towards a Comparative Glottodidactics (Modele kształcenia nauczycieli języków obcych w Polsce i w Niemczech. W strone glottodydaktyki porównawczej). Aside from the theoretical considerations it contains a set of detailed comparative analyses of the organisation and realisation patterns of foreign language teacher education in both countries as well as the results of research into the education processes of teachers of Polish as both foreign and second language. The author's concept of comparative glottodidactics complements the above topics.

\section{Towards a pedeutological study of teaching Polish as a second language.}

What deserves to be mentioned as the first academic insight to describe the education needs for teaching Polish as a second language, is the research project conducted by Krystyna Błeszyńska, affiliated with the University of Life Sciences (SGGW) in Warsaw. Funded by the Centre for Education Development and executed in 2010, the project was titled Children of Foreigners in Polish Education Facilities - from a Schooling Perspective (Dzieci obcokrajowców w polskich placówkach oświatowych - perspektywa szkoły) and its results unambiguously demonstrate the need to educate teachers of Polish as a second language. Błeszyńska also follows 
to underline the necessary restructuring of the education model for school pedagogues. In her opinion (...) such a person should combine the qualities of a pedagogue, psychologist, social worker and an expert in rehabilitation and revalidation. Any attempts to complement the specific areas of competence among the currently employed school pedagogues should be conceived with the above-mentioned modules in mind (Błeszyńska 2010: s.120). The same components should be applied in a selective fashion to the education process for the teachers of Polish as a second language.

The study by Błeszyńska has been taken into account in the undersigned's own project, partially comprised of pedeutological research into the professionalisation possibilities within the education processes for teachers of Polish as a foreign and second language. ${ }^{3}$.

The main goal of the project was the attempted verification of the glottodidactic components of education within the polonistic studies against the requirements of the contemporary occupational market in the education branch of teaching Polish to foreigners and individuals with migration backgrounds. In particular it was aimed at answering the question, whether the current academic curricula are relevant, as assessed by a group of active teachers who had previously graduated from these particular specialisations.

The project questionnaire had been conceived to gather information on four separate research areas including: general data; the current expectations among students of Polish as both foreign and second language; evaluation of any previous glottodidactical studies against the later experience of teaching Polish as both foreign and second language; self-estimation of own pedagogical and methodological competence.

The quantitative data had been acquired via an anonymous online form, with an accompanying letter to explain the goals and significance of the research at hand to the respondents. No SLA had been scheduled, however, a deadline was in place for submission of the completed questionnaires. In total the respondents were given two weeks to complete the survey tasks.

Over the course of the 2012-2013 survey, 19 individuals have responded. Among them 7 graduates of the third-cycle studies at the Centre for Polish Language and Culture in the World of the Jagiellonian University and 2 graduates of the glottodidactic specialisation at the "Polonicum", Centre of Polish Language and

\footnotetext{
${ }^{3}$ The research project as a whole has been accounted for in detail in a monograph published in Kraków in 2013 under the title: The Educational Models for Foreign Language Teachers in Poland and Germany. Towards a Comparative Glottodidactics (Modele kształcenia nauczycieli języków obcych w Polsce i w Niemczech. W strone glottodydaktyki porównawczej).
} 
Culture for Foreigners of the University of Warsaw. The remaining respondents had acquired their degree at the post-graduate studies at the Jagiellonian University (5) and the University of Warsaw (5).

Due to the constrictions of the local DPA a broader survey proved impossible to conduct. As a consequence, the results should only be regarded as a valid reference point for further systemic research, which shall hopefully be soon undertaken by the authorities responsible for language teacher education in Poland. These results, even though only based on a limited sample, have already indicated certain tendencies, allowing us to draw a series of conclusions vital to the organisation and realisation of the education process for teachers of Polish as foreign or second language.

In the case of the graduates of full-time studies the only available respondent group were the former students of the Cracovian JU Centre and the „Polonicum” facility in Warsaw. This was due to the fact that at the time of the survey no graduates from other universities, which have very recently launched their glottodidactic specialisations, had had a chance to appear within the education branch of the occupational market. ${ }^{4}$.

The group of respondents proved quite homogeneous with regards to ethnicity. 18 participants were of Polish and a single one of Russian origin.

Their average age on the other hand was rather low, ranging between 24 and 26 years of age in the case of third-cycle graduates and 24 to 30 among the post-graduates. In the former case not a single respondent was older than 35 , which should not come as surprising, given the fact that the type of education in question had only been available since 2005 .

The quality, comfort and success at work are strictly related to the pre-service education received by the active teachers of Polish as a foreign language. Consequently, to evaluate their received education in terms of organisation and execution would serve as important reference for any future modifications in the curricula. It is due to the above reason that our research among the graduates was mainly conceived to evaluate of the pre-service education.

The quality, comfort and success at work are strictly related to the pre-service education received by the active teachers of Polish as a foreign language. Consequently, to evaluate their received education in terms of organisation and execution would serve as important reference for any future modifications in the

\footnotetext{
${ }^{4}$ These include: The University of Łódź, The University of Wrocław, the Maria Curie-Skłodowska University in Lublin and the Pedagogical University of Kraków.
} 
curricula. It is due to the above reason that our research among the graduates was mainly conceived to evaluate of the pre-service education.

The relevant section of the survey was based on the 0-4 interval scale. Ranging from the 0 figure valued No opinion, through 1: Not constructive, 2: Moderately constructive, 3: Constructive to 4: Very constructive. The education modules, to which the values were to be attributed, have been defined in the survey with relevance to the existing academic courses, conducted at the universities in Kraków and Warsaw. The very classes which the respondents had attended to during their education. The applied variables reflect the general shape of the curricula, although this image is outdated by a few years, as it is worth to note, that the curricula have been modified in the meantime.

The results of the survey among the graduates of glottodidactic polonistic studies can be found in Table 2 .

This particular respondent group indicated the Methodology of teaching language skills and Pedagogical internship as the most constructive components of their education. The above two have been rated 4.0 at average, followed by Methodology of teaching language subsystems and European standards and frameworks for teaching foreign languages with the average value of 3.79. Further down the scale we could find Grammar in teaching P2L and descriptive polish grammar, Polish in Europe and the World as well as Results control in teaching, rated 3.58 (Av.). Literature in teaching P2L has also been rated on average above 3.0 (3.20), with the remaining components below that threshold. The graduates have rated the rest as follows: Polish among European languages at 2.95, Multimedia in teaching P2L at 2.93 and Teaching Polish culture at 2.32 .

In the following part of the survey the respondents were asked to indicate any components of their education which they found important, although they had not been included in the previous analytical section. Among the proposals we can find content quite parallel to the existing components, as well as other suggested, which are quoted below.

- Separate classes focused on teaching P2L to children with migration backgrounds.

- P2L stylistics.

- Teaching Polish culture, but with a more multicultural approach.

- What was lacking for me, were practical classes on how to use specialised software in teaching Polish. I'm aware, however, that such things are scarce.

- Good to include classes on how to teach P2l to immigrants.

- More grammar classes. How to teach it in a modern way? 


\begin{tabular}{|c|c|c|c|c|c|c|c|c|}
\hline 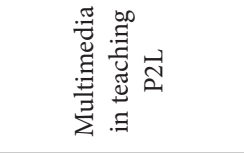 & $\stackrel{20}{7}$ & + & $\begin{array}{l}\hat{\kappa} \\
\hat{\sim}\end{array}$ & ల్లి & $\begin{array}{l}8 \\
m^{1}\end{array}$ & + & $\stackrel{\mathbb{D}}{\stackrel{్}{\rightarrow}}$ & 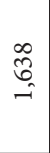 \\
\hline 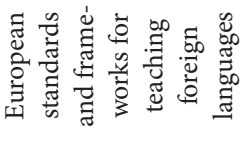 & 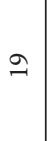 & 0 & $\underset{\hat{m}}{\stackrel{a}{n}}$ & ஜ̊ & $\stackrel{8}{\circ}$ & H & $\underset{F}{\nexists}$ & $\stackrel{2}{=}$ \\
\hline 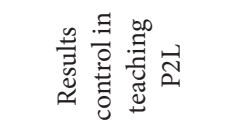 & 2 & 0 & $\begin{array}{l}\infty \\
\stackrel{\infty}{n} \\
m^{\prime}\end{array}$ & $\stackrel{\circlearrowright}{\exists}$ & $\begin{array}{l}8 \\
+\end{array}$ & $r$ & 命 & $\stackrel{\hat{n}}{\sim}$ \\
\hline 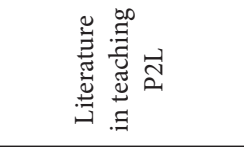 & $\stackrel{20}{\sim}$ & + & 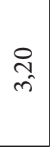 & $\stackrel{\circ}{\circ}$ & $\begin{array}{l}8 \\
m^{n}\end{array}$ & $m$ & $\vec{F}$ & 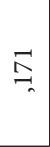 \\
\hline 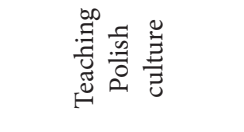 & 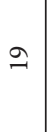 & 0 & $\begin{array}{c}\tilde{i} \\
i\end{array}$ & ָે & $\begin{array}{l}8 \\
i\end{array}$ & N & $\stackrel{\text { ô }}{-}$ & $\underset{-}{0}$ \\
\hline 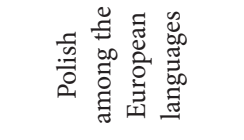 & 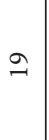 & 0 & $\begin{array}{l}\stackrel{2}{\alpha} \\
\hat{\sim}\end{array}$ & $\exists$ & $\begin{array}{l}8 \\
m^{n}\end{array}$ & $m$ & $\overrightarrow{\widetilde{b}}$ & $\begin{array}{l}\infty \\
\infty \\
m\end{array}$ \\
\hline 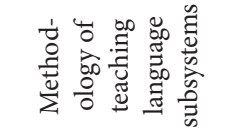 & 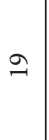 & 0 & $\begin{array}{l}\hat{I} \\
\hat{m}\end{array}$ & ถి & $\underset{f}{\Xi}$ & $\theta$ & $\underset{F}{F}$ & $\stackrel{2}{\cong}$ \\
\hline 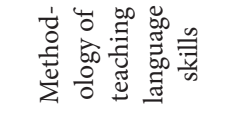 & 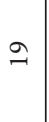 & 0 & $\underset{f}{8}$ & छి & $\begin{array}{l}8 \\
+\end{array}$ & + & ठ̊. & \& \\
\hline 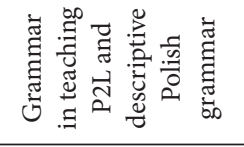 & $\curvearrowright$ & 0 & $\begin{array}{l}\infty \\
i_{n}^{\infty} \\
\stackrel{m}{2}\end{array}$ & $\begin{array}{l}\varrho \\
=\end{array}$ & $\begin{array}{l}8 \\
+\end{array}$ & 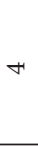 & है & $\stackrel{\hat{n}}{\sim}$ \\
\hline 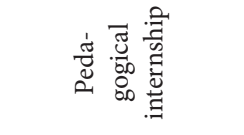 & 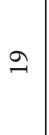 & 0 & $\stackrel{8}{+}$ & छ̊. & $\begin{array}{l}8 \\
+\end{array}$ & + & छ̊ & 8 \\
\hline 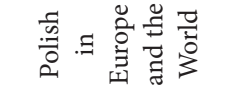 & 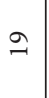 & 0 & $\begin{array}{l}\infty \\
\stackrel{\infty}{n} \\
m^{2}\end{array}$ & $\stackrel{0}{=}$ & $\stackrel{8}{+}$ & $r$ & 今े & ڤે \\
\hline & 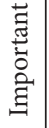 & 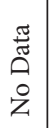 & 茛 & 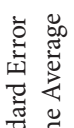 & పี & & 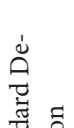 & 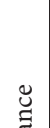 \\
\hline & \multicolumn{2}{|c|}{$z$} & 案 & 跑苛 & $\sum_{\Sigma}^{\infty}$ & $\sum^{\circ}$ & 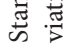 & $\bar{E}$ \\
\hline
\end{tabular}


The above results clearly demonstrate, that the graduates were mainly focused on content directly related to the practical teaching skills. On the other hand, what they rated as least constructive for an active teacher, corresponds to the fields of polonistic glottodidactics which are relatively the least developed, such as Multimedia in teaching P2L or Teaching Polish culture. The latter in particular has until very recently been often limited to conveying dreary facts and figures about Poland, which were hardly relevant to learning the language or the contemporary glottodidactic concepts of inter- and trans-cultural education. An approach more suited to teaching Polish as a foreign language, yet insufficient for the particular requirements of teaching $\mathrm{P} 2 \mathrm{~L}$.

The respondents have also expressed the obvious need to supplement the curricula with courses on teaching Polish as a second language. Such a demand, as mentioned above, had already been taken into account in the modified curricula at the JU Faculty of Polish as a Foreign Language, the Polish Philology Institutes at the University of Łódź and the Pedagogical University of Kraków as well as the WU Institute of Applied Polish Studies.

The degree of professionalisation in foreign language teacher education was reflected in creating stronger bonds between the theoretical knowledge and the teaching practice, and thus integrating the Pedagogical internship and the other components of teacher education into a coherent whole. The most important of these bonds lies in the courses on didactics and methodology, wherein the integration process should be conducted in a mindful and transparent manner, reinforcing the reflective meta-competence among the prospective teachers.

According to the respondents, the didactics \& methodology classes had fulfilled this goal, ensuring a thorough pre-service preparation for the future tasks of teaching Polish as a second language. Such was the opinion of 14 respondents (values Definitely yes and Rather yes). On the contrary 3 individuals have chosen Rather not or Definitely not). The remaining 2 have not given their account of this issue (value No opinion). The respondents who were satisfied with the level of constructiveness of their studies have simultaneously stressed the need to more closely bind the theory and practice together into a coherent whole. As much as 8 individuals have assessed the level of such coherency as unsatisfactory (value Rather $n o t$ ). Although the same number expressed their satisfaction with how relevant to one another the theoretical knowledge and the teaching practice had been (values Definitely yes and Rather yes).

The above statements translate directly to specific expectations towards the manner in which didactic and methodical classes should be conducted. According to the majority of the respondents such classes should follow the guidelines of the 
humanistic approach to teacher education, taking on an interactive form similar to workshops or seminars (see Table 3).

Table 3. The Professionalisation in Education - the expected formula of the practical classes in methodology, as viewed by the graduates (based on author's own research)

\begin{tabular}{|l|l|c|c|c|}
\hline \multicolumn{2}{|c|}{} & Practice classes & Workshops & Microlearning \\
\hline \multirow{2}{*}{$\mathrm{N}$} & Important & 17 & 17 & 17 \\
\cline { 2 - 5 } & No Data & 2 & 2 & 2 \\
\hline Average &, 24 &, 76 &, 82 \\
\hline Standard Error for the Average &, 106 &, 106 &, 095 \\
\hline Median &, 00 & 1,00 & 1,00 \\
\hline Mode & 0 & 1 & 1 \\
\hline Standard Deviation &, 437 &, 437 &, 393 \\
\hline Variance &, 191 &, 191 &, 154 \\
\hline
\end{tabular}

As many as 14 respondents have favoured the option to conduct classes in didactics and methodology in the manner of a workshop or seminar. 15 have indicated the value of introducing elements of microlearning into the curricula. This manner of teacher education, although primarily associated with the behavioural approach, can well be utilised, with proper modifications, within the humanities-oriented education. Only 4 respondents have confirmed the value of didactics and methodology taught in the form of traditional academic practice of the behavioural type, so widespread across the polonistic glottodidactic studies in Poland.

With certainty the research has answered multiple questions pertaining to the education of specialised staff to teach Polish as a foreign or second language. The results can be applied to verify and assess the current views and opinions, which continue to have a direct influence on the organisation and everyday pedeutological practice in the particular faculties.

The background hypothesis of the survey, that the active teachers of Polish as a foreign or second language are not always satisfied with the pre-service academic education, and that the current curricula are not always relevant to the requirements of contemporary occupational market in the education branch, has been supported. According to the results the graduates are rather satisfied with their pre-service education. They do claim, however, that the curricula are not always relevant to the requirements of contemporary occupational market in the education branch, 
Recapitulation. Re-organisation of the current pedeutological activities.

The polonistic glottodidactic community should endeavour to clearly divide their pedeutological proceedings into separate education modules for teachers of Polish as a foreign language and teachers of Polish as a second language. The obvious differences in the glottodidactic practice of the two above modules have also been confirmed by the students of various glottodidactic specialisations available at the polonistic studies. This discrepancy however, has yet to be appreciated by the Polish universities, where the design of the curricula in pedeutology remains focused on teaching Polish as a foreign language, and the attempts to simultaneously educate teachers of Polish as a second language along the same principles seems to be somewhat futile.

\section{References}

Aleksandrowicz-Pędich L., "Międzykulturowość na lekcjach języków obcych”, Uniwersytet w Białymstoku, Białystok 2005.

Gębal P.E., "Modele kształcenia nauczycieli języków obcych w Polsce i w Niemczech. W stronę glottodydaktyki porównawczej”, Księgarnia Akademicka, Kraków 2013.

Grucza F. (Ed.) "Problemy kształcenia nauczycieli języków obcych”, Wydawnictwo UW, Warszawa 1988.

Komorowska H., „Metodyka nauczania języków obcych”, Fraszka Edukacyjna, Warszawa 2002.

Kwiatkowska H., "Nowa orientacja w kształceniu nauczycieli", PWN, Warszawa 1988.

Marek E., "Przygotowanie do zawodu nauczyciela edukacji wczesnoszkolnej w Polsce”, Naukowe Wydawnictwo Piotrkowskie Filii Uniwersytetu Jana Kochanowskiego, Piotrków Trybunalski 2015.

Miodunka W.T. , Polszczyzna jako język drugi. Definicja języka drugiego, [in:] Silva rerum philologicarum. Studia ofiarowane Profesor Marii Strycharskiej-Brzezinie z okazji Jej jubileuszu, J. S. Gruchała, H. Kurek (Ed.), Kraków 2010, Wydawnictwo UJ, pp. 233-245.

Mizerek H., „Dyskursy współczesnej edukacji nauczycielskiej. Między tradycjonalizmem a ponowoczesnością", Wydawnictwo Uniwersytetu Warmińsko-Mazurskiego, Olsztyn 1999.

Pfeiffer W., „Nauka języków obcych. Od praktyki do praktyki”, Wydawnictwo Wagros Poznań 2001. Wilczyńska W., 2009, Nauczyciel języka obcego jako badacz, [in:] Nauczyciel języków obcych dziś i jutro, A. Mystkowska-Wiertelak, M. Pawlak, A. Pietrzykowska (Ed.), Kalisz 2009, Wydawnictwo WPA UAM, pp. 493-508.

Zawadzka E., „Nauczyciele języków obcych w dobie przemian”, Wydawnictwo Impuls, Kraków 2004.

Zawadzka-Bartnik E., „Nauczyciel języków obcych i jego niepełnosprawni uczniowie (z zaburzeniami i dysfunkcjami)", Wydawnictwo Impuls, Kraków 2010. 